Please note: This is an early draft of a published paper and should not be cited. Anyone wishing to cite this work should refer to the later published paper, which may contain some differences to this: Sadan, Mandy (2014) 'Remembering Fieldwork Histories.' In: Chaudhuri, S. K. and Chaudhuri, S. S., (eds.), Memories and Moments of Fieldwork: South Asian Experience. New Delhi: Sage Publications Pvt Ltd.

\title{
Remembering Fieldwork Histories
}

\author{
Mandy Sadan
}

\section{Prologue}

In the last eighteen months, Burma or Myanmar, has changed dramatically. Daw Aung San Suu Kyi has been released from house arrest, leading international statesmen and women have visited the country, censorship laws have been repealed and the international community has been facilitating the re-emergence of the country as a regional presence rather than a pariah. This chapter is a reflection upon fieldwork undertaken in the country at a time, during 1996-9, when changes of such scale and relative speed could not have been anticipated. Yet, many of the memories of this fieldwork relate to issues that have not been altogether resolved in the country: the Kachin State reverted to a stance of armed opposition after the breakdown of the ceasefire with the Burma Army in June 2011, and the prevalence of communal violence between Buddhists and Muslims has taken on alarming new forms as seen recently in the Rakhine State. In 1997, when this recollection begins, there were protracted, frequently violent outbreaks of communal protest in Burma between various Buddhist and Muslim groups in the country. Some of the most serious of these outbursts were seen in Mandalay, the historic capital of the last Burmese kings and a city proud of its distinctiveness. At this time, I was travelling through Mandalay hoping to get a boat to Bhamo, the important border trading town close to China which had long been a key site on the China to India trade route across the northern parts of Burma and the Kachin hills. ${ }^{1}$ The ceasefire that had been signed in 1994 between the Burma Army and the Kachin Independence Army had made such a visit viable, although it was still potentially sensitive. ${ }^{2}$ That evening, I like everyone else had to

\footnotetext{
${ }^{1}$ E. B. Sladen, "Expedition from, Burma, Viâ the Irrawaddy and Bhamo, to South-Western China," Journal of the Royal Geographical Society of London 41 (1871).

${ }^{2}$ Ashley South, Ethnic Politics in Burma: States of Conflict (Abingdon: Routledge, 2008).gives an account of the developments around this time at a general level. Martin T. Smith, Burma: Insurgency and the Politics of Ethnicity (London: Zed Books, 1999).remains the classic work on ethnic conflict in the country, although it was written principally before the ceasefires were signed.
} 
Please note: This is an early draft of a published paper and should not be cited. Anyone wishing to cite this work should refer to the later published paper, which may contain some differences to this: Sadan, Mandy (2014) 'Remembering Fieldwork Histories.' In: Chaudhuri, S. K. and Chaudhuri, S. S., (eds.), Memories and Moments of Fieldwork: South Asian Experience. New Delhi: Sage Publications Pvt Ltd.

remain inside as a night time curfew had been put in place to try to dissipate the tensions that seemed to build on an almost daily basis and to maintain order in face of the recent communal disturbances. In Burma at that time, there was heightened awareness among security officials and local populations that civic disorder of any kind could trigger more focused political protests, which would be dealt with severely. ${ }^{3}$

As in most urban areas, including the then-capital Yangon, electricity was an erratically supplied and sometimes entirely lacking resource at this time. Shut in my guest house room as the curfew descended, the lights went out and it looked set to be a long, hot, dark night. The owner brought a candle up to my room with the kind of embarrassed graciousness that was typical of many Burmese people who found themselves frustrated, angry and impotent in their current circumstances, yet who also had to make explanations to foreign visitors about things that were beyond their control. Sitting quietly in my room with the candle, I noticed that on the table in the corner of the room was a thick yellow book that looked very familiar. It was the Myanmar Yellow Pages. Today, more than sixteen years later, when internet cafes can be found in many places in the country and when we have becomes used to seeing images from inside Burma broadcast globally through the mobile phone and ICT networks that have built up within the country and across her borders, it is difficult to describe quite how absurd the concept of a 'Yellow Pages' seemed to be in Myanmar at that time. Telephones were still largely collective social objects where one often queued for a long time to be connected via recalcitrant operators along faulty lines. There seemed to be only a handful of phones in the whole of Mandalay during my visit. Intrigued by this apparent incongruity, I did what seemed the most rational thing to me at that time: I sat with my candle and read the Yellow Pages.

It is remarkable how interesting a text like the Yellow Pages can be when there is nothing else to hand. The walking finger trademark had been taken up by IMEX (Myanmar) Co. Ltd after 1993 with the aim of

\footnotetext{
${ }^{3}$ Bertil Lintner, Outrage: Burma's Struggle for Democracy (London: White Lotus UK, 1990). is a well known account of the 1988 protests and the brutality of the response to them by the military regime, which still defined the possible reactions towards any protests at this time.
} 
Please note: This is an early draft of a published paper and should not be cited. Anyone wishing to cite this work should refer to the later published paper, which may contain some differences to this: Sadan, Mandy (2014) 'Remembering Fieldwork Histories.' In: Chaudhuri, S. K. and Chaudhuri, S. S., (eds.), Memories and Moments of Fieldwork: South Asian Experience. New Delhi: Sage Publications Pvt Ltd.

promoting a modern business image of the country and facilitating business contacts with foreign companies. Yet it could not escape its reality. The idiosyncracies of the commercial environment at that time were there laid bare for anyone who had the time and rather train-spotterly interest in such things to take note of them. Despite my ongoing doubt that so many working telephones were actually present in the country at that time, after a couple of hours reading through the listings, some strange social shapes started to make themselves known: the place where astrologers tended to be concentrated became apparent, the area where traditional medicine sellers lived, and so on. It became a social document of the form and substance of commercial aspirations in Burma in the late 1990s.

It would be a rare lecturer who would advise his students that a night spent reading the Yellow Pages in the dark was a night spent doing Fieldwork. Yet such events were highly typical of the process by which I started to learn about the intriguing country in which I was now living. First, there was no possibility of controlling a field of research in any long-term way, and second, the aspiration to do so would have been flawed from the outset, so intricate and dense were the complexities of urban life in Burma's towns at this time. I soon learned that asking questions only resulted in receiving answers; in contrast, listening, rather than speaking, following rather than leading, led to questions, answers, discussions, and lines of thought that could not be anticipated, opening up areas of knowledge and learning that were much more vital and penetrating. When stuck in a black out, in a curfew, one's mind can only turn to trying to understand how that situation has arisen with whatever one has to hand, and to piece together the minute, even infinitesimal fragments of peoples' daily lives that together bring meanings. The mindset that encouraged me simply to sit back and start reading the Yellow Pages if that was all there was to hand served me well in Burma in seeking out the qualitative embedded in the quantitative, the sublime in the banal, and it is this mindset that ultimately defined the fieldwork journey that I was to take. 
Please note: This is an early draft of a published paper and should not be cited. Anyone wishing to cite this work should refer to the later published paper, which may contain some differences to this: Sadan, Mandy (2014) 'Remembering Fieldwork Histories.' In: Chaudhuri, S. K. and Chaudhuri, S. S., (eds.), Memories and Moments of Fieldwork: South Asian Experience. New Delhi: Sage Publications Pvt Ltd.

\section{Fieldwork memories}

A small group of us sat together in an upstairs office in the Kachin-owned company Jadeland in downtown Yangon. It was late in 1996 and it had been just two years since the Kachin Independence Army (KIA) had signed a ceasefire with the central regime, then referred to by the acronym SLORC (State Law and Order Restoration Council). ${ }^{4}$ No one knew at this time what the implications and consequences of the ceasefire would be, or even if it would last. ${ }^{5}$ However, for the time being, it meant an end to armed conflict in most of the far north of the country, large parts of which had been under KIA control following a protracted armed conflict which had started in 1961. The ceasefire was a controversial affair and the manner of its brokerage remains a contentious subject in Kachin politics today. The 'Lahtaw Brothers' as some referred to the ceasefire's principal civilian brokers on the Kachin side, Reverend Saboi Jum and Khun Myat, were seen by some Kachin people as having forced a situation of compliance upon the KIA and its civil wing, the Kachin Independence Organisation (KIO), without adequate discussion or foresight of its consequences; self-seeking business interests were sometimes invoked to explain the primary rationale of those promoting the ceasefire. For those negotiating the ceasefire, however, the devastating social consequences of long-term conflict and the need to stop the endless pressures upon Kachin families to give up the lives of their sons and daughters to become permanent, unpaid recruits in a conflict that seemed increasingly unviable as a means of bringing about political resolution seemed justification enough for their actions. Neither was this the first time that attempts had been made to bring about an end to the conflict; other discussions had been held intermittently throughout its three decades or more of destruction, but the collapse of negotiations in the early 1980s seemed to herald a newly brutal and irresolvable

\footnotetext{
${ }^{4}$ and Win Min Zaw Oo, Assessing Burma's Ceasfire Accords (Washington, D.C.; Singapore: East-West Center Washington; ISEAS Publishing, 2007).

${ }^{5}$ K. Woods, "Ceasefire Capitalism: Military-Private Partnerships, Resource Concessions and Military State Building in the BurmaChina Borderlands," Journal of Peasant Studies 38, no. 4 (2011).
} 
Please note: This is an early draft of a published paper and should not be cited. Anyone wishing to cite this work should refer to the later published paper, which may contain some differences to this: Sadan, Mandy (2014) 'Remembering Fieldwork Histories.' In: Chaudhuri, S. K. and Chaudhuri, S. S., (eds.), Memories and Moments of Fieldwork: South Asian Experience. New Delhi: Sage Publications Pvt Ltd.

phase of conflict that took a decade to turn into another opportunity for a tenuous 'peace'. ${ }^{6}$ For some, the opportunity presented in 1994 was not a capitulation but an opening that could and should not be shut.

I came to be sitting in the Jadeland office through a surprising and wholly unanticipated set of circumstances. In April 1996, when I arrived to work in Burma as one of the foreign teaching staff in the newly opened Direct Teaching Operation at the British Council in Yangon, there were a host of similar issues impacting upon many so-called 'border' regions of Burma. The country was undergoing some of the most dramatic economic and political changes it had seen for many decades, and, indeed, that was the sole reason we were allowed to be there. Following the suppression of political protests against the military regime in 1988, and the events of the 1990 elections when the National League for Democracy, with Daw Aung San Suu Kyi at its head, won and were then denied power, ceasefires had been brokered with many armed non-state groups across the county. In 1989 the regime had announced a new 'Open Door' economic policy, which was intended to entice foreign business investments and, although rather erratic in its implementation and operation, this resulted in more foreign businesses taking the bold, perhaps rash step at this time of opening trading and other links with the regime. For decades under the Burma Socialist Party Programme (BSPP), which took control of the central functions of the state under General Ne Win in 1962 and which was the only party allowed to exist from 1964 to 1988 , foreigners had been allowed to visit the country on seven day tourist visas, and Burma rightly gained its reputation as being one of the most closed countries in the world to outside eyes. When it was declared that Visit Myanmar Year was to be promoted in 1996, it seemed an odd concept, to say the least. Arguments raged internationally about the need for boycotts and sanctions following the winning of the 1990 election by the National League for Democracy and the subsequent house arrest of Daw Aung San Suu Kyi and others. The Lady's statement that tourists should not come to the country was heeded by many, but touristspotting became a strange and even increasingly enjoyable distraction for local tea shop customers in downtown

\footnotetext{
${ }^{6}$ Smith, Burma: Insurgency and the Politics of Ethnicity
} 
Please note: This is an early draft of a published paper and should not be cited. Anyone wishing to cite this work should refer to the later published paper, which may contain some differences to this: Sadan, Mandy (2014) 'Remembering Fieldwork Histories.' In: Chaudhuri, S. K. and Chaudhuri, S. S., (eds.), Memories and Moments of Fieldwork: South Asian Experience. New Delhi: Sage Publications Pvt Ltd.

Yangon by the end of 1996, with badly-tied, often incorrectly gendered traditional Burmese skirt cloths, with acres of hairy white flesh displayed beneath, apparently being the dress of choice for those who decided to enter the country, as they tried, impossibly, to 'blend in'. This was a time of enormous transitional potential, but it could also be a time of military entrenchment at the centre: the field of play was not clear at this time. However, one thing was increasingly certain, and that was that when any such changes might be introduced, it would never be completely possible to go back to what had previously been.

The British Council had been allowed to bring in three foreign teachers to help improve the standard of English teaching in Burma. As it turned out, the Burmese teachers who had already kept the ship afloat for many years were far better than us in almost every way. The field of action open to the British Council at this point was still not clear and whether the new operation should be primarily oriented towards its business potential or its grant-in-aid functions seemed a point of dispute within the organisation and between some of its own staff at this time. In 1996 Burma had only recently begun to loosen slightly its restrictive policies on longterm habitation in the country by foreigners, especially western ones. To live in the country for such an extended period was, at the time, quite unusual, although it is now rather commonplace.

Just after our arrival in April 1996, someone ran into the British Council offices and shouted "Come and look outside! There's a traffic jam!" It was the country's first. One of the other very noticeable changes in urban Yangon at this time, aside from the mind-boggling speed with which the number of second-hand Japanese motor cars seemed to increase exponentially to clog up every street, was the almost overnight development of a technology 'sector'. When we foreign teachers arrived, our Burmese colleagues were already far more adept at using a PC than we were and they, as in so many other things, led and we had to follow. The opening of some limited trading connections and Burma's entry into ASEAN in 1997 meant that computer shops began to spring 
Please note: This is an early draft of a published paper and should not be cited. Anyone wishing to cite this work should refer to the later published paper, which may contain some differences to this: Sadan, Mandy (2014) 'Remembering Fieldwork Histories.' In: Chaudhuri, S. K. and Chaudhuri, S. S., (eds.), Memories and Moments of Fieldwork: South Asian Experience. New Delhi: Sage Publications Pvt Ltd.

up all over Yangon, and gradually other principal urban areas, although the supplies of ink cartridges and other resources could vary noticeably from month to month.

Yet from September 1996, the universities were again closed by the regime following student protests. This time, however, a large body of young people started eagerly to take up the low-cost computer training courses that proliferated, fees being covered by families in the regions or by siblings and cousins working (usually illegally) abroad. Desktop publishing and the availability of better quality printing papers produced an expansion of the printed public sphere that, although still heavily censored, created new opportunities for the subversion of its control than did the time-consuming, labour intensive process of manual typing and Gestetner copying. Looking back, these changes were highly significant in making the developments that have been seen recently possible on a social level, indeed they contributed to making necessary and possibly to a large degree irreversible.

Although I initially worked for the British Council, this role was soon superseded by the increasing involvement I had in an archive digitisation project that materialised between myself on behalf of the Green Centre for World Art at Brighton Museum, UK, and an organisation called the Yup Uplift Committee. This relationship was also partly a product of the changes just described which made even thinking about a 'digitisation project' a possibility rather than a fantasy. My linkage with the museum had developed out of a Masters Degree in Art and Archaeology for the School of Oriental and African Studies, London University. This degree was still being completed upon arrival in Burma. The Masters dissertation considered a collection of photographs held at Brighton Museum taken by Colonel James Henry Green. Colonel Green had worked as a recruitment and military intelligence officer in the Indian Army in Burma throughout the 1920s and the early 
Please note: This is an early draft of a published paper and should not be cited. Anyone wishing to cite this work should refer to the later published paper, which may contain some differences to this: Sadan, Mandy (2014) 'Remembering Fieldwork Histories.' In: Chaudhuri, S. K. and Chaudhuri, S. S., (eds.), Memories and Moments of Fieldwork: South Asian Experience. New Delhi: Sage Publications Pvt Ltd.

1930s. ${ }^{7}$ During that time the officer had collected a large number of artefacts such as textiles and had compiled an impressive photographic collection derived from his experiences. Significant portions of these collections related to the Kachin region where he had been a recruitment officer for the Burma Rifles and had also been engaged in military survey and intelligence duties along the northern borders with China. Colonel Green's most noteworthy achievement amongst his peers seems to have been the extension he oversaw of the Kachin Rifles recruitment field to the Nung region north of Putao in non-administered territory. ${ }^{8}$ His documentation of this expedition through the collection of photographs and items of material culture has subsequently proved to be of significance in the historical representation of this area.

In Burma I had in my possession a selection of about three hundred randomly selected photocopied images from Colonel Green's photographic archive and started to make enquiries about them. As news of these images spread to the Kachin communities resident in Yangon, largely through students who were attending the British Council because their university educations had come to a grinding halt, I was brought into contact with members of the Yup Uplift Committee. The Yup Uplift Committee was headed by Pungga Ja Li, a former Baptist pastor and well-known cultural researcher and commentator, but it had been initiated and supported by some of the most prominent elders in the Kachin Baptist Convention and Theological College in Myitkyina. Since 1992 the Committee had been attempting to make audio and video recordings of key 'Kachin' indigenous spirit rituals and related performances as part of a cultural documentation project. The assumption today is that 'most' Kachin people inside Burma are Christians of various denominations, the figure of $90 \%$ or more usually being cited, although the Baptist and Catholic churches are the largest congregations. ${ }^{9}$ However, certain elites from within the Baptist church (although similar concerns are expressed by members of other church groups),

\footnotetext{
${ }^{7}$ Dell E., 'Mapping Burma: the James Henry Green Collection of photographs', Burma Frontier Photographs 1918-1935, London: Merrell Publishers, 2000, pp.9-27.

${ }^{8}$ M. Sadan, "Historical Photography in Kachin State: An Update on the James Green Collection of Photographs," South Asia: The Journal of the South Asia Studies Association of Australia Special issue: Northeast and Beyond: Culture and Change (2007).

${ }^{9}$ François Robinne, Prêtres Et Chamanes: Métamorphoses Des Kachin De Birmanie (Paris: Harmattan, 2007), H. G. Tegenfeldt, A Century of Growth: The Kachin Baptist Church of Burma (South Pasadena, California: William Carey Library, 1974).
} 
Please note: This is an early draft of a published paper and should not be cited. Anyone wishing to cite this work should refer to the later published paper, which may contain some differences to this: Sadan, Mandy (2014) 'Remembering Fieldwork Histories.' In: Chaudhuri, S. K. and Chaudhuri, S. S., (eds.), Memories and Moments of Fieldwork: South Asian Experience. New Delhi: Sage Publications Pvt Ltd.

felt increasing concern during the years of conflict that all knowledge of previous non-Christian indigenous cultural practices was disappearing as the rituals were no longer being performed. These elites were typically those who had themselves experienced the process of conversion to Christianity or had direct experiential knowledge of indigenous spirit practices. The founders of the Committee did not desire to restore these former ritual practices but rather desired to 'salvage' the communicative and cultural social memory that was deemed to be embedded in them: knowledge of genealogies, of cultural paradigms, social behaviours, and the indigenised historical experience of place and space effected through the ritual consolidation of social and cultural relationships. This documentation was made possible by the control that the KIA had over the larger part of the Kachin region during the early 1990s but the support that had been given to the programme by these church elders was also critical. Some of the recording activities went under the guise of missionary activity as a means of persuading local Christian nationalist KIA officers that recordings should take place.

The committee had been funded by a local Kachin businessman, called Yup Zau Hkawng. Whilst the ceasefire undoubtedly brought economic opportunities to Yup Zau Hkawng and others of his ilk, they coincided with great pressures upon the economic bedrock of their businesses - the extractive jade trade. A small network of Kachin jade bosses had built up a significant business in mining and selling on jadeite into China, where it would be carved and put into the Chinese, Hong Kong and Taiwanese market by Chinese traders. ${ }^{10}$ The wealth from this trade was vast beyond belief and access to this resource was significant both for the development of the economics of conflict in the Kachin region, and the modern distinctiveness of Kachin society relative to other 'minorities' in conflict with the Burmese military government. Yet ceasefire also heralded greater control of the jade mines by the Burmese military regime. KIA control of the jade mines area was now reformulated through the trading company Buga, and Yup Zau Hkawng and other jade bosses found their worsening

\footnotetext{
${ }^{10}$ A. and Scott-Clark Levy, C., The Stone of Heaven: The Secret History of Imperial Green Jade (London: Weidenfeld and Nicolson, 2001).
} 
Please note: This is an early draft of a published paper and should not be cited. Anyone wishing to cite this work should refer to the later published paper, which may contain some differences to this: Sadan, Mandy (2014) 'Remembering Fieldwork Histories.' In: Chaudhuri, S. K. and Chaudhuri, S. S., (eds.), Memories and Moments of Fieldwork: South Asian Experience. New Delhi: Sage Publications Pvt Ltd.

economic position started to impact upon their ability to define their own course through the politico-economic minefield. ${ }^{11}$ Yup Zau Hkawng, as many other Kachin businessmen, operated a loose ship financially with economic realism watered down by a traditional Hhahku proclivity towards showy, symbolic displays of wealth and generosity, and an ever-expanding circle of needy people and their causes demanded his attentions. The original Yup Uplift Committee, which had undertaken the cultural recordings, had a vision not only of a museum in a computer but of a giant festival that would establish the Kachin cultural and political space of Myitkyina as a Kachin stronghold. These ideas were still being formulated at this time. This was before the grand manau festivals had become established as a cultural icon, the zenith of which was a reported 300,000 people attending the massive cultural festival and business expo at the end of 2001 which heralded the manau community dance festival as the major symbol of modern Kachin identity. This future was not guaranteed in 1996.

Despite these considerable difficulties the workers of the Committee had amassed an impressive collection of audio-visual and photographic materials from across the Kachin region, the cultural and historical value of which could not be underestimated. These recordings included ritual performances in ritual context as well as studio renderings of oral performance in ritual language. However, by 1996 the harsh weather conditions as well as an investigative probe conducted by government Military Intelligence officers, who suspected a Kachin nationalist agenda, meant that this archive was in an extremely disordered and vulnerable state. My role became that of facilitating information exchange between the Green Centre for World Art and local Kachin researchers with the objective of enhancing the data on the UK collections and providing technical support for the preservation of the local archive through its digitisation. I frequently found myself from this

\footnotetext{
${ }^{11}$ Woods, "Ceasefire Capitalism: Military-Private Partnerships, Resource Concessions and Military State Building in the BurmaChina Borderlands.", K. Woods, "Community Forestry in Cease-Fire Zones in Kachin State, Northern Burma: Formalizing Collective Property in Contested Ethnic Areas" (paper presented at the CAPRi Workshop on Collective Action, Property Rights and Conflict in Natural Resources Management, Siem Reap, Cambodia, 2010).
} 
Please note: This is an early draft of a published paper and should not be cited. Anyone wishing to cite this work should refer to the later published paper, which may contain some differences to this: Sadan, Mandy (2014) 'Remembering Fieldwork Histories.' In: Chaudhuri, S. K. and Chaudhuri, S. S., (eds.), Memories and Moments of Fieldwork: South Asian Experience. New Delhi: Sage Publications Pvt Ltd.

point sitting in the office in Jadeland, Yup Zau Hkawng's company, talking with a group of later middle-aged Kachin men who had spent all their lives in a conflict zone in one of the world's most internationally isolated countries. It did not at the time seem as surprising as it perhaps should have done, that one of their intentions in wanting to work collaboratively with myself and the Green Centre for World Art at Brighton Museum in the UK was that they hoped to develop 'a museum in a computer'.

It was this which had brought us together, and this group already had grand, very expensive ambitions as to what they wanted to do with the material they had collated and how it could be used to revitalise knowledge of 'traditional' Kachin cultural practices. The idea of a 'museum in a computer' seemed perfectly logical and reasonable even in Burma at this time, so rapid had local communities appreciated the potential of a newly dawning 'digital age' in the country and our whole research project, as it became, in some ways coalesced around this kind of virtuality: we dealt almost entirely with imagined spaces and peoples, of imagined times and their convergence within a technical space that could be used to transcend the everyday. The Yup Uplift Committee had a notion that the process of 'salvage', effected through digital archiving, might assist, amongst other things, with the production of historical narratives counter to those promoted by the Myanmar military government on the historical integrity of the ethnic category 'Kachin', and thus the historical base of their claims to autonomous control over a distinctive territory within the modern state. In 1998-99 this developed further into a local publication project, again initiated by the local research committee as part of their cultural agenda, which transcribed and translated from Jinghpaw ritual dialect into Jinghpaw colloquial idiom a key ritual recitation with explicative commentary, making use of the new desktop publishing facilities that had begun to expand. This was part of the attempt by this committee and its supporters to increase understanding of the non-Christian past and to develop new meaning frameworks for traditional modes and models of nonChristian communicative and social memory in contemporary society. Clearly this was a very particular moment of possibilities, which brought together technological potential, limited international communication 
Please note: This is an early draft of a published paper and should not be cited. Anyone wishing to cite this work should refer to the later published paper, which may contain some differences to this: Sadan, Mandy (2014) 'Remembering Fieldwork Histories.' In: Chaudhuri, S. K. and Chaudhuri, S. S., (eds.), Memories and Moments of Fieldwork: South Asian Experience. New Delhi: Sage Publications Pvt Ltd.

and a respite from conflict to create a space for reciprocal intellectual enquiry and exchange. It was a 'fieldwork' opportunity that was created by our common interests and curiosity and yet could not have been constructed externally or anticipated.

It soon became apparent that for my role to be effective, it would be necessary for me to make a detailed study of the rituals and ritual language that had been recorded by the Yup Uplift Committee so that I could understand the nature of the materials with which we were dealing. From the publication project in particular I learned of some of the ways in which non-Burman speech communities, as well as non-Buddhist religious communities, were able to manipulate the state's censorship of cultural output in small but politically significant ways, as well as the modes by which cultural and historical counter- narratives in minority nationality languages can be developed through networks that function beyond the tight grasp of the official censorship board. The value, role and possible implications of this audio, video and photographic archive were nonetheless highly contested within many Kachin communities and interest groups at this time. Gradually I learned about some of the problematics of contemporary Kachin nationalist identity discourses, especially when engaged in the representation of Kachin history, the impact of colonialism, the Christian missions, and the meaning frameworks of modernity and 'tradition'. I was privileged to witness firsthand the development of such discourses and to learn about the mechanisms by which these difficulties can be negotiated within local discourses conducted in Jinghpaw, the principal 'Kachin' language. ${ }^{12}$

My encounter with the problematics of ethnic representation was not confined solely to a Kachin context, however. In 1996 I came into contact with the ethnographic video production company, AV Media, run by the Rakhine-born producer U Win Tin Win. The public output of this company, which was designed to be consumed in tourist hotels and airports, gave no indication of the difficulties that were faced by the cameramen

\footnotetext{
${ }^{12}$ For a more complete and extensive representation of the full outcomes of this collaboration see M Sadan, Being and Becoming Kachin: Histories Beyond the State in the Borderworlds of Burma (Oxford: The British Academy and Oxford University Press, 2013).
} 
Please note: This is an early draft of a published paper and should not be cited. Anyone wishing to cite this work should refer to the later published paper, which may contain some differences to this: Sadan, Mandy (2014) 'Remembering Fieldwork Histories.' In: Chaudhuri, S. K. and Chaudhuri, S. S., (eds.), Memories and Moments of Fieldwork: South Asian Experience. New Delhi: Sage Publications Pvt Ltd.

and producers to create even this ostensibly 'soft' material; the company subsequently went out of business due to the increasing and unbearable pressures that were being placed upon it. The strict enforcement of censorship and its haphazard and erratic mode of operations rendered all such output open to a bizarre array of random demands for the inclusion and exclusion of material as the censor board adopted a mode not of regulation but of subtle and persistent harassment. However, the public output was but a fragment of a rich collection of videographic material that had been made throughout the country since the 1980 s by these local cameramen with local contacts and through local eyes. Through this relationship I had access to one of the most remarkable contemporary visual archives of festivals, places and customs as the team travelled endlessly trying to record the changing face of Burma and its varied social and cultural life through the lens of Burmese photographers. This uncut footage would be discussed in the office by the predominantly Burman staff as they related their experiences of being Burman in these non- Burman majority areas, their prejudices and assumptions, their sympathies and empathies and the constraints on understanding within the political and educational framework in which they had been raised. In addition, I learned of the aesthetic-political process of editing and script writing for the submission of ethnographic videos for the official censor; how control was asserted not only over the representation of ethnic minorities but also over the ethnography of every-day life for the Burman communities around the country and the different social, cultural and historical models that were allowed to pertain in these representations. Over a two and half year period of being involved in this process, I began to appreciate some of the complexities of how the state manipulated its public consumption of ethnographic images in a range of fields and, again, how strategies and networks operated subtly to contest this control.

Without a specific research agenda of my own, the discourses I engaged in with these various groups became in itself a focus of interest to me, as I sought to unravel and understand the confusing complexity of what it meant to be, or be labelled 'Kachin' in the modern Burmese state, why that label itself was objected to but also manipulated by nationalists, as well as how it was interpreted by sympathetically and non- 
Please note: This is an early draft of a published paper and should not be cited. Anyone wishing to cite this work should refer to the later published paper, which may contain some differences to this: Sadan, Mandy (2014) 'Remembering Fieldwork Histories.' In: Chaudhuri, S. K. and Chaudhuri, S. S., (eds.), Memories and Moments of Fieldwork: South Asian Experience. New Delhi: Sage Publications Pvt Ltd.

sympathetically minded non-Kachin people. Intuitively I learned that there was a core historical problematic that need to be explored and the 'fieldwork', if it can even be described as such, was an exercise in defining and unravelling that intuited problematic, as much as an attempt to resolve it. The key element in this 'fieldwork' became the sometimes laborious daily process that we undertook to translate inter-culturally (Jinghpaw to English) and intra-culturally (ritual Jinghpaw to colloquial Jinghpaw) the ritual recitations that had been recorded during the early 1990s from across the Kachin region. It is in this process that I am mindful of my willingness to read the Yellow Pages, for it was this that made the collaboration possible. These difficult performances, recited in couplet phrases using a now almost disappeared ritual lexis, may last for many hours, are accompanied by complex and intricate sets of ritual practices, and have now almost ceased to take place in the Kachin region of Burma on any significant scale.

Yet it was the triangulation of translation that was critical in this research. From the intra-cultural perspective, the extended amount of time that we spent carefully decoding every word, line by line, became a fascinating process for me of also observing the evolution of explanations, as my understanding increased, as their trust in me deepened, and as my own critical abilities improved. It was about extracting the qualitative from the quantitative and the sublime from the banal. The explanatory commentary was an evolving and transformative process, not a linear one. This experience has perhaps been the most formative intellectually of my life in how I approach understanding this area. A full text parallel text of ritual and colloquial Jinghpaw was the outcome of this collaboration by 1999. This was of a translation of a recitation at a performance called Lanyi. ${ }^{13}$ The Lanyi, which was recited at weddings after the bride had entered the family home of the groom, was performed by the dumsa, or indigenous spirit priest, Chyahkyi Brang in 1992. This performance is intended both to honour the new bride, and to instruct her as to the ways of a good wife in a new family. The term Shanhpyi Laika or 'Leather Book' was used to describe the broader series of works that the Committee then

${ }^{13}$ Pungga Ja Li, Shanhpyi Laika: Lanyi, Yangon: A Z Offset, 1999. 
Please note: This is an early draft of a published paper and should not be cited. Anyone wishing to cite this work should refer to the later published paper, which may contain some differences to this: Sadan, Mandy (2014) 'Remembering Fieldwork Histories.' In: Chaudhuri, S. K. and Chaudhuri, S. S., (eds.), Memories and Moments of Fieldwork: South Asian Experience. New Delhi: Sage Publications Pvt Ltd.

hoped to produce. As in many other parts of Asia where similarities of practice are seen, this term evokes missionary ethnography, by which the development of Jinghpaw literature was equated with the recovery of the internalised spirituality that the ancestors had consumed (through the body of a buffalo called Nga Shaga) on their migration from Mahtum Mahta, the point at which humans separated from spirits as they migrated to human habitation. The transcribed text was selected because, as a didactic discourse, it was deemed less provocative towards the still highly sceptical Christian nationalist majority, who still suspected that these research activities would lead to Kachin Christian unity being undermined. Significantly, the recitation was not sub-divided into ritual sections around offerings made to a particular spirit but could be abstracted from the ritual proceedings that preceded it during the day of the wedding. This particular recitation was also one of the most complete performances that the research team had been able to record of this ritual, and Chyahkyi Brang was considered to be a very fine dumsa.

The development of this work started to reveal the complexities of how the abstracted text related to the original oral performance and how the colloquial translation should be in turn related to that of the transcribed original form performed in ritual language. In this there were also significant difficulties arising from the censorship of text over many decades and related socio-educational constraints, due to the fact that a very limited textual corpus in Jinghpaw was available for people to read, other than religious tracts. Kachin people, it was felt, would have multiple difficulties not only in reading the text but also in understanding its structure and how to use items such as footnotes, these being unseen in Jinghpaw texts until this time. Not only would the reader have to be oriented to the recitation and translation as an unusual encoding of Jinghpaw communicative social memory, they would also have to be oriented to the text as a material object. The solutions to these problems were found in making a tape to accompany the book, which presented extracts from the original recitation to help orientate people to the sound and structure of the original language. The transcription and translation were line-numbered and cross-referenced, and a brief introduction described how to use footnotes 
Please note: This is an early draft of a published paper and should not be cited. Anyone wishing to cite this work should refer to the later published paper, which may contain some differences to this: Sadan, Mandy (2014) 'Remembering Fieldwork Histories.' In: Chaudhuri, S. K. and Chaudhuri, S. S., (eds.), Memories and Moments of Fieldwork: South Asian Experience. New Delhi: Sage Publications Pvt Ltd.

and other references. Footnotes were used for some of the expository commentary relating to individual items of lexis that might be particularly significant or obscure. Each chapter was also prefaced with a short introductory statement in which the context of the following section was summarised and interpretations given where appropriate. The text was illustrated with drawings made by a local graphic artist, and was produced to the highest standard that was then possible inside Burma, using Kachin technicians and designers where possible. As the book was for public sale and use, it had to be submitted to the official censor. This could have been avoided if it had been presented as a religious tract. However, this would have necessitated the formation of an officially sanctioned group or Committee, which would have had to declare itself as 'Animist'. This was deemed to be playing into the hands of those who felt indigenous spirit practices would be divisive of Kachin religious unity in the present. Yet, as a non-Burmese language text, it was possible to submit a summary of the text's contents in Burmese for approval, reflecting the generally poor understanding that the apparatus of the central state had of minority languages and cultures, but which offered a slight window of opportunity that minority language cultures could exploit. It was decided, therefore, to present the text to the censor under the rubric of being a clan or family history, being the recitation made at the wedding of a particular family, in order to obtain official sanction. If it had been presented as a book on Kachin history, the text would have been prohibited as being a nationalist discourse.

The translation by Pungga Ja Li was criticised by some elites who had personal recollection of these forms by stating that the poetic and aesthetic aspects of the original were lost too much by rendering them in a translated colloquial form. Nonetheless, the text was at the time of considerable significance in providing a new model by which ritual language could be re-presented in contemporary Kachin society, as well as challenging the boundaries of what it was felt could be achieved intellectually and technologically in repositioning these forms for a new, youthful, Christian-oriented audience. It achieved this partly by the material structure that was given to the text, which elevated it as a high-quality publication evoking academic models of presentation. This 
Please note: This is an early draft of a published paper and should not be cited. Anyone wishing to cite this work should refer to the later published paper, which may contain some differences to this: Sadan, Mandy (2014) 'Remembering Fieldwork Histories.' In: Chaudhuri, S. K. and Chaudhuri, S. S., (eds.), Memories and Moments of Fieldwork: South Asian Experience. New Delhi: Sage Publications Pvt Ltd.

directly challenged the Christian nationalist social memory construction of ritual language, which stigmatised it as a form that personified illiteracy and degeneracy. ${ }^{14}$ As a result, the social networks in which this text was used demonstrated the transformation of the meaning frameworks of oral ritual in contemporary society that began to take place. In 2002 the text was used in a newly constituted Kachin Culture and Literature Summer School in Myitkyina, which had the support of the Kachin Baptist Church. Most recently it has been serialised on the principal Kachin language community radio programme Wunpawng Daini over a period of weeks. Significantly, this, like the Summer School, was a youth-run programme, although the radio programme is sponsored by opposition organisations and appeals mainly to Kachin youth in a global diaspora. It was this youth community that was in the late 1990s most antagonistic towards research on historical Kachin culture and dismissive of any attempt to reconfigure understandings of the ritual language. Clearly there had been a shift in contemporary social memory towards this form in the last five years as contemporary nationalist discourse again repositions the meanings of its own past. It is clear also that it was the direct challenge to the representation of the ritual language as a medium of potential disunity and degeneracy that helped to effect this change. However, the transfer from individual memory to social memory of these forms has inevitably necessitated a great loss in detailed knowledge of ritual and cultural forms as the language remains abstracted from its ritual context. Furthermore, the semiotic shift of the forms to the entrenched cognitive encoding of the Christian missions is equally unavoidable, not only in the transfer of semantic ritual domains in the translation of the Jinghpaw Bible, but also through the censorship and social networks within which the text of this recitation have been taken up as a material object with something to say about the social memory of the Kachin peoples.

The whole process for me, however, was an experience of such daily intensity that I know that I will probably never be able to replicate such an intellectual experience again, and it has remained absolutely

\footnotetext{
${ }^{14}$ Sadan, "Historical Photography in Kachin State: An Update on the James Green Collection of Photographs."
} 
Please note: This is an early draft of a published paper and should not be cited. Anyone wishing to cite this work should refer to the later published paper, which may contain some differences to this: Sadan, Mandy (2014) 'Remembering Fieldwork Histories.' In: Chaudhuri, S. K. and Chaudhuri, S. S., (eds.), Memories and Moments of Fieldwork: South Asian Experience. New Delhi: Sage Publications Pvt Ltd.

fundamental to almost everything I have thought or written on this subject since then. The intensity of the study was critical. It is in this that I think my willingness to sit down and read the Yellow Pages in that dark, hot room in Mandalay is indicative of the kind of mindset that one needs to persevere in these circumstances with difficult but frequently tedious detailed explorations of the minutiae of lives that one does not fully understand. Every day we would spend hours discussing sometimes just a few words from these performances, with long, meandering explanations reaching off into many detailed areas of Kachin cultural history that I could never see either then or possibly in the future. Two lines might occupy us for three or four days, with the heat, with illness, with all the other daily problems that living in Yangon entailed also frequently slowing us down. The process of digitisation was equally slow and laborious. As the 1998 World Cup approached, the electricity supply became almost non-existent, with it being widely believed that this was to ensure that electricity could be guaranteed during the event. Sure enough, during that time were had the first steady electricity supply for many months, albeit during the hours of midnight and two in the morning; this then became our working time. During one notable period it took us nearly three months to successfully print out sixty pages of transcriptions as the availability of an electricity supply, a computer without hardware or software problems caused by the surges and slumps in the current, and a working printer with ink proved too much of a challenge to bring together all at one time. It was an interest and a commitment that could not be faked, and that won me many friends. There are still many unresolved questions arising from this time, but we all in our various ways continue with the work that we elaborately constructed together during those three years. Many young people who became involved in the network of those interested in the work have gone on to do significant work in developing cultural projects with young people in the Kachin region, in developing language and literacy courses in advanced Jinghpaw, and in developing education based projects for young Kachin people struggling to maintain their place in the state education system. It was an unrepeatable experience for all of us concerned, and continues to provide a thread many years down the line, and into the future. 
Please note: This is an early draft of a published paper and should not be cited. Anyone wishing to cite this work should refer to the later published paper, which may contain some differences to this: Sadan, Mandy (2014) 'Remembering Fieldwork Histories.' In: Chaudhuri, S. K. and Chaudhuri, S. S., (eds.), Memories and Moments of Fieldwork: South Asian Experience. New Delhi: Sage Publications Pvt Ltd.

\section{Epilogue}

Just before I left Burma in 1999, sitting on the banks of the Irrawaddy River in Myitkyina, the capital of Kachin State in northern Burma, and just downstream of the bridge that was then being built to improve the infrastructure to the China border, I was given a Jinghpaw name by means of a short ritual. Ginger had been pounded together with dried fish, and then I and other members of my new family sat together and ate it, swilling back a few cups of rice beer as we did so. Following this, I was fully adopted into the Pungga family of the Jinghpaw Maran clan. Ba Li, as I should thereafter refer to the man who was now my older brother, had given me this name as a means of paying respect to the relationship we had built up over the previous years, but also because he knew it would help me out. 'If you want to do more research about Kachin', Ba Li said, 'you will need this name. Now, wherever you go in Kachinland, when you meet someone who is Kachin they will automatically be a relative and they will assist you.' I had entered into a new social space where the first point of reference with anyone to whom I was introduced should always be a kinship relationship. These kinship terms articulate a complex transnational network of real and imagined historical relationships between Jinghpaw -speaking peoples spanning territories in North East India, Burma, Yunnan and beyond. Ba Li had given me my Jinghpaw name so that I could establish closer relationships with Kachin people across this transnational space that constitutes one of the borderworlds of South, East and Southeast Asia. The Jinghpaw of Burma, the Singpho of North East India, the Jingpo of Yunnan were historically and are today socially intricate parts of a commonly understood non-national cultural zone. This zone, whose fluid boundaries may be defined in part by social use of the Jinghpaw language, usually in combination with a range of other national and nonnational languages and not necessarily with Jinghpaw as the dominant gloss, has evolved both in relation to the multiple state systems with which it is in contact, as well as in line with its own internal logic of social explanation. In the decade following the gifting of my name, I have had more experience of this space and have entered into it along a number of disciplinary and geographical routes. The more I have done so, the more I am 
Please note: This is an early draft of a published paper and should not be cited. Anyone wishing to cite this work should refer to the later published paper, which may contain some differences to this: Sadan, Mandy (2014) 'Remembering Fieldwork Histories.' In: Chaudhuri, S. K. and Chaudhuri, S. S., (eds.), Memories and Moments of Fieldwork: South Asian Experience. New Delhi: Sage Publications Pvt Ltd.

amazed at its ability to integrate and enable articulation of a common sense of autonomous being in relation to the intersecting vectors of the Indian, the Chinese and the Burmese states. This was a characteristic that was clearly historically produced, but more than this it seemed to me a process that existed in an ontological relationship with time and the possibilities for consistency within transformation; it was produced within and by state systems, but also above and beyond them. Ba Li was right. As I criss-crossed this zone, within five minutes of meeting any person who might categorise themselves broadly-speaking as 'Kachin', my status as either sister, cousin, mother, grandmother or aunt was established from China to India.

Increasingly I have been able to test the premise of these imagined relationships as my research has extended to the west, east and southeast of Burma. These experiences remain largely unstructured as I still like to allow for the possibility of just allowing things to happen and unfold and to try to understand the ways in which things happen and unfold, rather than forcing them to unfold in particular ways. As I have done so I have had to reconfigure and reposition my previous learning in relation to new social situations, new political environments and new cultural and religious dilemmas. This has also opened up the possibility of looking at lines of discourse and how they develop over time, to introduce a further temporal dynamic into the framework of learning. From this one can begin to see an alternative model of fieldwork emerging that is pertinent more to the historical than the anthropological, a form of praxis that might take on the name Fieldwork History should its method and reasoning ever become formalised. Such a praxis is vital if we are to understand the histories rather than just the ethnographies of environments that are excluded from our traditional historical gaze. Adding the temporal into our understanding does not always involve a deep chronological framework; rather it can emerge through a process of repeated interaction, of shifting interaction, and which seeks to draw out historical process rather than anthropological constants as its main focus. In this way, slowly it may be possible to begin to write the histories of marginal spaces according to their own internal dynamics and frames of reference. 
Please note: This is an early draft of a published paper and should not be cited. Anyone wishing to cite this work should refer to the later published paper, which may contain some differences to this: Sadan,

Mandy (2014) 'Remembering Fieldwork Histories.' In: Chaudhuri, S. K. and Chaudhuri, S. S., (eds.), Memories and Moments of Fieldwork: South Asian Experience. New Delhi: Sage Publications Pvt Ltd. 
Please note: This is an early draft of a published paper and should not be cited. Anyone wishing to cite this work should refer to the later published paper, which may contain some differences to this: Sadan, Mandy (2014) 'Remembering Fieldwork Histories.' In: Chaudhuri, S. K. and Chaudhuri, S. S., (eds.), Memories and Moments of Fieldwork: South Asian Experience. New Delhi: Sage Publications Pvt Ltd.

\section{Brief Bibliography}

Levy, A. and Scott-Clark, C. The Stone of Heaven: The Secret History of Imperial Green Jade. London: Weidenfeld and Nicolson, 2001.

Lintner, Bertil. Outrage: Burma's Struggle for Democracy: London: White Lotus UK, 1990.

Robinne, François. Prêtres Et Chamanes: Métamorphoses Des Kachin De Birmanie Paris: Harmattan, 2007.

Sadan, M. Being and Becoming Kachin: Histories Beyond the State in the Borderworlds of Burma. Oxford: The British Academy and Oxford University Press, 2013.

Sadan, M. "Historical Photography in Kachin State: An Update on the James Green Collection of Photographs." South Asia: The Journal of the South Asia Studies Association of Australia Special issue: Northeast and Beyond: Culture and Change (2007): 457-77.

Sladen, E. B. "Expedition from, Burma, Viâ the Irrawaddy and Bhamo, to South-Western China." Journal of the Royal Geographical Society of London 41 (1871): 257-81.

Smith, Martin T. Burma: Insurgency and the Politics of Ethnicity London: Zed Books, 1999.

South, Ashley. Ethnic Politics in Burma: States of Conflict. Abingdon: Routledge, 2008.

Tegenfeldt, H. G. A Century of Growth: The Kachin Baptist Church of Burma. South Pasadena, California: William Carey Library, 1974.

Woods, K. "Ceasefire Capitalism: Military-Private Partnerships, Resource Concessions and Military State Building in the Burma-China Borderlands." Journal of Peasant Studies 38, no. 4 (2011): 747-70.

. "Community Forestry in Cease-Fire Zones in Kachin State, Northern Burma: Formalizing Collective Property in Contested Ethnic Areas." Paper presented at the CAPRi Workshop on Collective Action, Property Rights and Conflict in Natural Resources Management, Siem Reap, Cambodia 2010.

Zaw Oo, and Win Min. Assessing Burma's Ceasfire Accords. Washington, D.C.; Singapore: East-West Center Washington; ISEAS Publishing, 2007. 